\title{
MONITORING A CONDITION OF RECOVERY OF RESIDUAL STAND AND LOGGED OVER AREA AFTER 5 YEARS RIL IMPLEMENTATION: A CASE STUDY AT A FOREST COMPANY IN CENTRAL KALIMANTAN
}

\author{
Sukanda ${ }^{1}$, Yuniawati ${ }^{1}$ and Sona Suhartana ${ }^{1}$
}

\begin{abstract}
The aim of this study were to identify and evaluate a condition in logged over area (LOA) after 5 years of reduced impact logging (RIL) implementation, and to asses how far recovery of former skidding road, damages in felled and yarded over area, and environmental condition had taken place. Results of this study was expected to provide inputs and to improve the RIL implementation guidance for sending sustainable forest management. The results revealed that: (1)The covers of skidding road reached consecutively $2,641 \mathrm{~m}^{2}$ area (in block I), and $3,147 \mathrm{~m}^{2}$ area (in block II), as both marked by the growing of bushes with coverage portions i.e. $84 \%$ and $80 \%$, respectively; (2) The bush that grew on the former skidding road was regarded as pioneer vegetation; (3) The effect of cross drain on skidding road after logging was able to decrease erosion, and increase the recovery of the road condition; and (4) The healthy residual stand after 5 years logging by RIL showed that small diameter felled trees have resulted bigger residual stand damaged then big diameter or the percentage of healthy trees would be small.
\end{abstract}

Keywords: LOA, RIL, residual tree stands, small diameter trees, damaged and healthy stands

\section{INTRODUCTION}

Forestry development is an important sector in supporting national development. The trend of national development is to increase potential of Indonesia's natural resources and secure the pleasant environment by doing conservation, rehabilitation and utilization of natural resources economically such as through the implementation of low-impact logging technology (Anonim, 2000). However, implementation of forest logging in the field showed that almost all operations are still focused on economic aspects rather than ecological aspects (Suhartana et al., 2000; Suhartana and Dulsalam, 2000; Suhartana, 2001; Suhartana, 2002; Suhartana, 2002 ${ }^{\text {b) }}$.

Almost all logging activities have been done mechanically using heavy equipments so that environmental damage could not be avoided. The use of heavy equipments can induce changes in forest-stand environments and soil physical characteristics. The changing and disturbance of condition of natural resources caused by logging activities will affect environmental aspects and further will influence soil property. In improper logging techniques implementation, there tend to increase environment damages thereby it will decrease log supply to wood industries.

\footnotetext{
${ }^{1}$ Forest Product Research and Development Center, Bogor
} 
Some study results which showed environmental damage caused by logging activities are presented in Tables 1 and 2. These tables revealed that conventional logging activities that did not follow the sustainable-forest principles caused an extensive forest damage. These problem could be solved by implementing the so called reduced impact logging (RIL). RIL put forward a concept to minimize the forest damage caused by logging activity, i.e. planning, process, and post-logging activities.

Table 1. Residual stand damages caused by conventional felling (in two locations, i.e. West Kalimantan and Jambi)

\begin{tabular}{clcc}
\hline \multirow{2}{*}{ No. } & \multirow{2}{*}{ Aspect } & \multicolumn{2}{c}{ Residual stand damage $(\%)$} \\
\cline { 3 - 4 } & & West Kalimantan & Jambi \\
\hline 1 & Range & $9,85-14,83$ & $12,04-18,26$ \\
2 & Mean & 11,75 & 15,28 \\
3 & Standard deviation & 2,18 & 2,50 \\
4 & Coefficient of variation & 18,55 & 16,38 \\
\hline
\end{tabular}

Source : Dulsalam et al. (2000)

Table 2. Residual stand damages caused by conventional skidding (in two locations, i.e. Riau and Jambi)

\begin{tabular}{clcccc}
\hline \multirow{2}{*}{ No } & \multirow{2}{*}{ Aspect } & \multicolumn{2}{c}{ Residual stand damage $(\%)$} & \multicolumn{2}{c}{ Ground exposure $(\%)$} \\
\cline { 2 - 6 } & & Riau & Jambi & Riau & Jambi \\
\hline 1 & Range & $13,3-23,8$ & $17,19-24,14$ & $18,75-24,25$ & $8,60-15,40$ \\
2 & Mean & 18,25 & 20.23 & 21,06 & 12,23 \\
3 & Standard deviation & 4,31 & 3,40 & 2,41 & 2,54 \\
4 & Coefficient of variation & 23,62 & 16,81 & 11,44 & 20,77 \\
\hline
\end{tabular}

Source: Suhartana et al. (2002)

TPTI (Tebang Pilih Tanam Indonesia/Indonesian Selective Cutting System) guidelines deal with forest inventory techniques, allowable trees cutting, and forest harvesting treatments to ensure an adequate natural regeneration. The system are aimed to properly maintain and utilize the forest regarding with sustaining production of natural forest. RIL should be considered to manage natural production forest in Indonesia. RIL potentially reduced damage associated with logging, promoting more rapid re-growth of logged over area and increased productivity of commercial timber species.

Sustainable forest management strategy must be implemented to minimize the effect of logging activity on environment, and always to keep the forest stand productive and healthy. Globally, deforestation is a strong political issue. Indonesian tropical forest has been recognized as the world's lung which can keep the world ecosystem from environmental degradation and impairment. A good forest utilization policy is obviously strategic to show our seriousness and can be a proof regarding the successful implementation of sustainable forest management fact without losing economic advantage. 
Recently, RIL is promoted being inspired by the implementation of eco-labeling for tropical forest. Many studies have been done to minimize the disastrous effect of forest logging. Further, how well the area condition is progressing after 5 years of the RILimplemented logging needs to be monitored.

The aims of this study were to identify and to evaluate conditions of forest stand in logged over area after 5 years of the RIL-implemented logging and to examine how far the recovery of former-skidding road, felled and yarded over area, in severe damage, and environmental condition had progressed.

\section{METHODOLOGY}

\section{A. Time, Location, and Tools}

This research was conducted in 2003 in former areas of RIL implementation trial situated in the Wanariset Sangai, plots 1, 2, 5, 6, 7, and 8, under the administrative working area of logging concession (PT Kayu Tribuana Rama Figure 1), in Tumbang Sangai village, Mentaya Hulu sub-district, Kota Waringin Timur district, Central Kalimantan with the cover area of 98,765 Ha (SK Menhut No. 1002/Kpts-VI/1999, 14 October 1999).

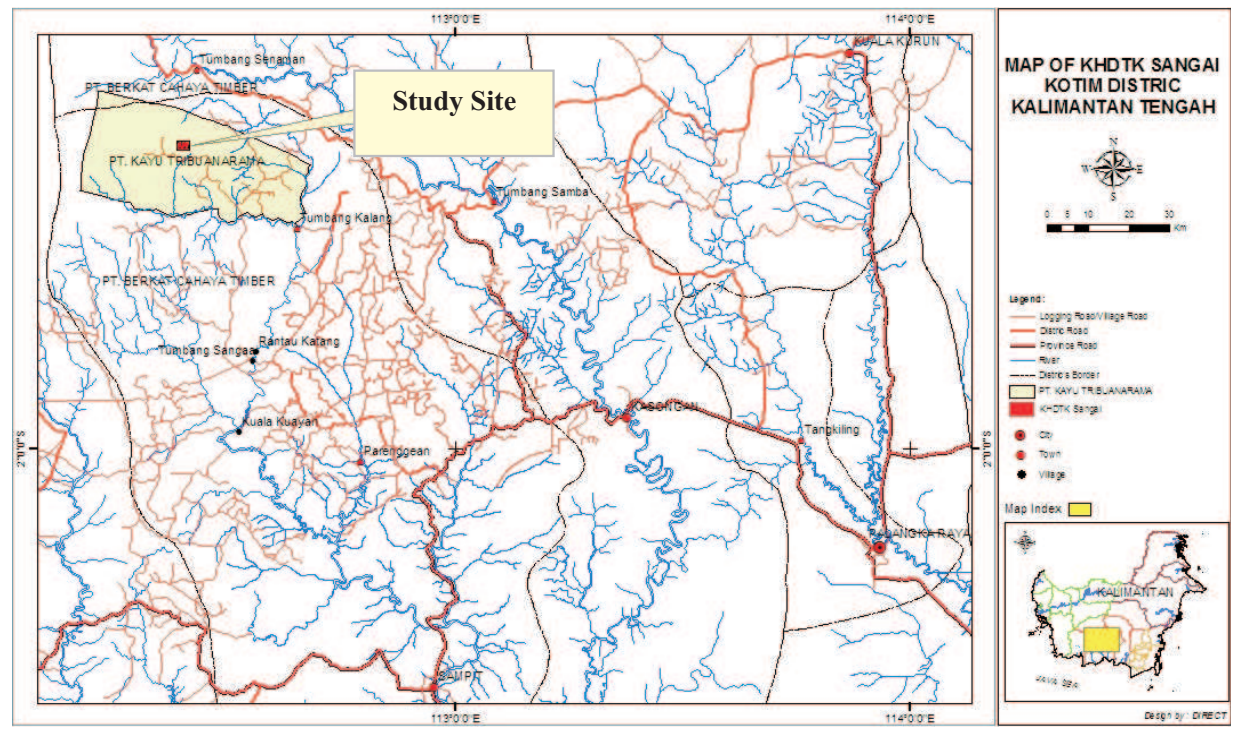

Figure 1. Study site map in the Wanariset Sangai, plots 1, 2, 5, 6, 7, and 8 in Central Kalimantan 
The material and tool used in this research are measuring meter, stationeries, and computer.

\section{B. Procedures}

The stages of this research were:

1. Observation on a condition of recovery at a former skidding road after logging.

a. To observe possible changes of soil cover condition at the former skidding road.

Measurement of soil covers was carried out on skidding roads following their utilization under some particular conditions. Those roads consisted of main skidding, branch skidding, and sub-branch skidding roads. The measurement was also intended to assess intensity of the changes on the soil cover.

b. To observe the changes of soil-recovery condition on the former skidding road.

Condition of soil recovery on the skidding road was examined by observing erosion flow on the skidding road. This was also intended to evaluate how much the effect of crossdrain development had occurred to the recovery condition of the skidding road. Crossdrain is a water channel on former skidding road. The channel is built with $45^{\circ}$ elevation to skidding road to reduce the impacts of erosion.

2. Observation on changes in the cover condition of the logged-over area (LOA).

a. Observation on changes in the cover condition of LOA.

Measurement of soil covers on damaged area following the felling and skidding operations were by observing those covers through the sapling of commercial species, pioneer species, or bushes. This observation took place on open areas brought about by felling and skidding activities on the central plot of that area.

b. Observation on health and dead rate of damaged trees

After felling activity, there were many damaged trees. The aim of this observation was to assess the tree health condition after 5 years of felling. The trees were randomly selected to measure their recovery level.

\section{Data Analysis}

The changes occurring in the residual stands and LOA were observed, and analyzed statistically using average observed values, standard deviation and coefficient of variation (Steel and Torrie, 1980). Further, the analyzed results were utilized to improve work elements of RIL techniques.

\section{RESULTS AND DISCUSSIONS}

\section{A. Recovery at the Former Skidding Road after RIL Implementation}

1. Soil cover at former skidding road after 5 years of RIL implementation

The effect of logging activity using RIL on ground exposure in Wanariset Sangai is presented in Table 3 . The table showed that skidding road exposure after 5 years of logging activity was about $82 \%$ covered by vegetation. Length of skidding road has caused erosion in the first year. The skidding road which was quite long in distances induced erosion in the first 
year of activity. After 5 years, however, on low-level soil displaced skidding road, it was covered by bushes, pioneer climber (meremia). This brought about the termination of soilparticle erosion.

Table 3. Skidding road exposure caused by the logging (RIL) and vegetation covers in recovery process of skidding column after 5 years logging

\begin{tabular}{|c|c|c|c|c|}
\hline \multirow{2}{*}{$\begin{array}{c}\text { Felling } \\
\text { block }\end{array}$} & \multirow{2}{*}{$\begin{array}{l}\text { Area } \\
(\mathrm{Ha})\end{array}$} & \multirow{2}{*}{$\begin{array}{c}\text { Skidding road } \\
\text { exposure } \\
\left(\mathrm{m}^{2}\right)\end{array}$} & \multicolumn{2}{|c|}{$\begin{array}{l}\text { Vegetation covers on the } \\
\text { skidding road }\end{array}$} \\
\hline & & & $\left(\mathrm{m}^{2}\right)$ & $(\%)$ \\
\hline I & 27 & 2,641 & 2,218 & $84 \%$ \\
\hline II & 32 & 3,147 & 2,517 & $80 \%$ \\
\hline Mean & 29.5 & 2,894 & 2,517 & $82 \%$ \\
\hline
\end{tabular}

On the main and branch skidding roads after 5 years logging, some species were growing, i.e. Macarangga sp, Endospermum and Antocephalus chinensis. On sub-branch skidding road where the soil was not disturbed and only 1 to 3 times passed by tractor, Dipterocarpaceae species was encountered.

2. Soil condition at the former skidding road after 5 years of RIL implementation

The first effect of logging using RIL is the risk of severe erosion. However, after 5 years there was no erosion anymore because the soil at the former skidding road has been covered by vegetation.

Cross drain development on skidding road with $45^{\circ}$ elevation in skidding-road direction has decreased erosion and increased recovery condition of skidding road. It can be seen from the amount of mud or soil particle that was eroded and collected at every system interval that skidding road soil will covered by vegetation. As a result, skidding road that has been covered by vegetation will recover more quickly because the soil is protected from erosion and the soil is always moist so that microorganism can survive.

\section{B. Changes in LOA Condition}

1. Changes in condition of LOA cover

The result of the study showed that the less severely disturbed area has been covered by bushes and species of Dipterocorpaceae i.e: Dryobalanops lanceolata Burk, Hopea dryobalanoides Mig, Shorea maxeliana King, Shorea parvitiha Dayer, Shorea fanaflora King, Shorea muluflora, Shorea laevis, Shoreapinanga, and Hopea sp.

Dipterocarpaceae species is the main element essential for stand development at tropical rain forest. With the assumption that the next growth and development of seedling will proceed normally it will ensure forest regeneration process for developing commercial natural forest stand.

The result showed that at some felled trees with some felling cuts could decrease disturbance on crown exposure. By felling regulation imposed on RIL system, this could 
Journal of Forestry Research Vol. 4 No. 1, March 2007: 45 - 51

decrease crown exposure to ensure growth level of Dipterocarpaceae species and to limit pioneer growth.

2. Health and death rate of damaged trees

The healthy residual stand situation after logging by RIL at varied diameter of felled trees are presented in Table 4. The table also showed the proportions of residual stands on classified by their diameters, i.e. $40 \mathrm{~cm}$ up, $50 \mathrm{~cm}$ up, and $70 \mathrm{~cm}$ up were $59 \%, 67 \%$ and $71 \%$ respectively. Further, within each of those diameter classes, the number of healthy residual stands varied. It is interesting that the smaller the diameter of felled tree, then the greater the number of damaged residual stands or the fewer the number of healthy residual stands. These phenomena in fact corresponds to those of Siapno (1970), who stated that the residual tree stands can stay good if the logging operation provides healthy trees at $60-65 \%$ portion. In this way, therefore through the implementation of RIL logging, the occurrance of erosion exposure could be reduced.

Table 4. Number of trees before and after logging by RIL at various diameter of felled trees

\begin{tabular}{|c|c|c|c|c|}
\hline \multirow{2}{*}{$\begin{array}{l}\text { Diameter of felled trees } \\
\qquad(\mathrm{Cm})\end{array}$} & \multirow{2}{*}{$\begin{array}{l}\text { Plot } \\
\text { No }\end{array}$} & \multirow{2}{*}{$\begin{array}{c}\text { Number of trees before } \\
\text { logging } \\
\text { (Trees) }\end{array}$} & \multicolumn{2}{|c|}{$\begin{array}{c}\text { Number of healthy trees after } \\
\text { logging }\end{array}$} \\
\hline & & & (Trees) & $(\%)$ \\
\hline \multirow[t]{2}{*}{40 up } & 01 & 510 & 297 & 58 \\
\hline & 05 & 668 & 407 & 60 \\
\hline Mean & - & 589 & 352 & 59 \\
\hline \multirow[t]{2}{*}{50 up } & 06 & 736 & 487 & 66 \\
\hline & 08 & 519 & 351 & 67 \\
\hline Mean & - & 627 & 419 & 67 \\
\hline \multirow[t]{2}{*}{70 up } & 07 & 551 & 402 & 73 \\
\hline & 02 & 499 & 343 & 69 \\
\hline Mean & - & 525 & 373 & 71 \\
\hline
\end{tabular}

\section{CONCLUSION}

1. Skidding road cover in block I reached $2,641 \mathrm{~m}^{2}$ area. Meanwhile, the cover area in block II was $3,147 \mathrm{~m}^{2}$. Both area (in blocks I and II) were covered by bushes at $84 \%$ and $80 \%$ proportion, respectively.

2. The effect of cross drain on skidding road after logging could decrease erosion and increase the recovery of skidding road condition.

3. The area of low disturbance to soil has grown up by bushes and Dipterocarpaceae species.

\section{REFERENCES}

Anonymous 2000. Ketetapan-ketetapan Majelis Permusyawaratan Rakyat - Republik Indonesia dalam Sidang Umum MPR RI tanggal 1-21 Oktober 1999. BP Dharmabakti. Jakarta. 
Dulsalam., S. Suhartana, D. Tinambunan., M. Sinaga, dan Sukadaryati. 2000. Penebangan pohon yang efisien dengan kerusakan tegakan tinggal minimal. Laporan Hasil Penelitian Pusat Penelitian Hasil Hutan Bogor tahun 2000. Unpublished.

Siapno, I. B. 1970. Guide for the injury study. Hand Book of Selective Logging, $2^{\text {nd }}$ Edition Manila, Philipines. 279pp.

Steel, R. G. D. and J. H. Torrie. 1980. Principles and Procedures of Statistics. Mc Graw-Hill Book Co., Inc. New York. 633pp.

Suhartana, S., Dulsalam, dan M. M. Idris. 2000. Penyaradan terkendali untuk minimasi penggeseran lapisan tanah atas dan keterbukaan lahan : kasus di suatu perusahaan hutan di Kalimantan Tengah. Buletin Penelitian Hasil Hutan. Pusat Penelitian dan Pengembangan Hasil Hutan. Bogor. 17: 209-219.

Suhartana, S dan Dulsalam. 2000. Pemanenan berwawasan lingkungan untuk minimasi kerusakan hutan. Buletin Penelitian Hasil Hutan. Pusat Penelitian dan Pengembangan Hasil Hutan. Bogor. 18: 87-103.

Suhartana, S. 2001. Pengaruh penebangan terkendali dan konvensional terhadap kerusakan tegakan tinggal dan produktivitas kerja. Buletin Penelitian Hasil Hutan. Pusat Penelitian dan Pengembangan Hasil Hutan. Bogor. 19: 219-230.

.2002 ${ }^{\mathrm{a}}$. Pemanenan berwawasan lingkungan (PBL) berbasis luasan petak tebang untuk mengurangi kerusakan tegakan tinggal di salah satu perusahaan hutan di Riau. Jurnal Standardisasi 4 : 47-54, November 2002. Badan Standardisasi Nasional. Jakarta.

2002 . Dampak pembalakan berwawasan lingkungan (PBL) terhadap kerusakan tegakan dan biaya penyaradan di hutan produksi alam. Buletin Penelitian Hasil Hutan 20 : 285-301. Pusat Penelitian dan Pengembangan Hasil Hutan. Bogor.

Suhartana, S., Dulsalam dan Sukadaryati. 2002. Penyaradan berwawasan lingkungan untuk minimasi kerusakan hutan dan biaya di hutan produksi alam. Laporan Hasil Penelitian Pusat Penelitian dan Pengembangan Teknologi Hasil Hutan Bogor tahun 2001. Unpublished. 